\title{
On processes of coloniality and decoloniality of knowledge: notions for analysing the international history of mathematics teaching
}

\author{
Gert Schubring $^{1}$ (D) \\ Accepted: 28 March 2021 / Published online: 12 May 2021 \\ (c) The Author(s) 2021
}

\begin{abstract}
The aspiration of this paper is to develop a novel approach towards investigating the socio-political history of mathematics teaching in educational systems. Traditionally, historical studies are confined to just one country, the author's country. Broader approaches address international developments by confronting and comparing global and local aspects-revealing general patterns and more specific 'local' structures and characteristics. Yet, already in antiquity and medieval times, the specific characteristic of mathematics teaching, namely to operate at the crossroads of general education and vocational training, proved to be intimately tied to the functioning of the particular political system. In pre-modern times, however, a truly international pattern emerged for the first time: European powers conquered, occupied and colonised overseas regions. Given that educational systems were emerging at the same time within these states, they often transmitted elements of these structures to their colonies. This phenomenon included mathematics, and the history of its teaching is analysed here as a part of coloniality. It is shown that this was not a uniform process, and the differences between the various colonial powers are discussed. The involvement of mathematics in the process of decolonisation is addressed, as well as its role in the tension between continued coloniality and movements of decoloniality. Finally, the general framework provided for studying socio-political processes connected with establishing mathematics teaching within public educational systems is applied, in order to analyse recent coloniality practices effected by international achievement studies.
\end{abstract}

Keywords Public education policy $\cdot$ Colonial powers $\cdot$ Orientalism $\cdot$ PISA

\section{Introduction}

In this paper I take a novel approach to the international socio-political history of the teaching of mathematics in a cross-cultural perspective. Since mathematics teaching within public educational systems is by now globally, essentially, structured according to the educational systems of one or other European states, as a continuation of European colonial policy from about $1500 \mathrm{CE}$ on, the development of these structures is analysed here by means of the concepts of coloniality and decoloniality. Since this conception is claimed to be applicable to recent decolonisation, the paper also discusses possible decoloniality insights for post-Soviet studies regarding Eastern European states. Finally, the more

Gert Schubring

gert.schubring@uni-bielefeld.de

1 Bielefeld University, Bielefeld, Germany recent establishment of international achievement tests is studied from this perspective.

A general history of mathematics teaching must begin by studying developments in antiquity. All early cultures and civilisations elaborated some forms of mathematical practices and transmitted them to certain groups of the next generation. If early states were involved in these transmissions, these occurred in the form of training professionals to serve the state's functions-scribes in the Old Babylonian $e d u b b a$, surveyors in Pharaonic Egypt, and mandarin functionaries in the Chinese School of Computation. Even in the Greco-Roman world, there was no state intervention for any form of general education or for providing mathematics teaching at large. Likewise, in Islamic civilisation, the states did not assume the function of establishing a school system (see Schubring, 2015).

To study state initiatives for a public school system and a role of mathematics within it, one has to focus on Europe from pre-modern times. The rise of new state functions reveals a particular pattern shown by Max Weber's famous 
1905 thesis on Protestant Ethics as the basis of modern capitalism. It attributed the rise of capitalism to a specific geographical and religious constellation, namely, to Western Europe and the Protestant Reformation. While Weber attributed this economic development to one of the two main Protestant directions, to Calvinism, the educational impact of the Protestant Reformation involved both Protestantism and Catholicism-orthodox Christianity was not affected directly by the Reformation and contributed less to developing educational structures. Indeed, the entirety of Western Europe established at least germs of state initiatives for public education-first, due to the imperative sola gratia and its consequence that every believer should be able to read the bible, thus instituting the teaching of reading and writing in Protestant territories, and second, as a consequence, the Catholic Counter-Reformation and its militant Jesuits order creating secondary schools (colleges) in Catholic countries.

In the first section, it is discussed how educational systems became established in Western Europe in pre-modern times, albeit with a marginal status for mathematics. This period coincided with the first colonial expansion of European countries to other continents and implied some transmission of educational structures. Today, after the colonial period, one can observe systems modelled according to some European state in all countries of the world-and with mathematics unquestioned as a major teaching subject. How this hegemony came about will be the main subject of analysis, including recent aspects of the practices of coloniality and decoloniality.

The approach proposed here goes quite beyond the relation between metropolis and periphery, or between centre and periphery, concepts used within sociology of science to investigate the transmission of knowledge. Regarding the history of mathematics in the eighteenth century, one can describe, for example, mathematics in Portugal as situated at the periphery-yet it is not connected with any practice of coloniality by some European centre. The essential feature here is constituted by the establishment of mathematics teaching overseas in the wake of colonialism.

\section{The concepts of coloniality and decoloniality}

The concepts of coloniality and decoloniality have been developed recently, in particular by Catherine E. Walsh (Ecuador) and Walter D. Mignolo (USA), to analyse continued Eurocentric practices on a global scale with reference to former colonial countries and the fostering of local, differing practices called "decolonial attitudes" (Walsh, 2018, p. 17). It is a radical critique of a "colonial power matrix" exercised by European powers since about 1500-including the US policies for more recent periods-imposing Occidental modes on other cultures and societies. The concept can also be applied to studies of post-Soviet countries (Walsh, 2018):

Decoloniality denotes ways of thinking, knowing, being, and doing that began with, but also precede, the colonial enterprise and invasion. It implies the recognition and undoing of the hierarchical structures of race, gender, heteropatriarchy, and class that continue to control life, knowledge, spirituality, and thought, structures that are clearly intertwined with and constitutive of global capitalism and Western modernity. [...] Decoloniality, in this sense, is not a static condition, an individual attribute, or a lineal point of arrival or enlightenment. Instead, decoloniality seeks to make visible, open up, and advance radically distinct perspectives and positionalities that displace Western rationality as the only framework and possibility of existence, analysis, and thought. (p. ii)

One has to emphasise the difference between "decolonisation" and "decoloniality": while the first term expresses the political process of a former colony obtaining its independence, "decoloniality" means the process of overcoming coloniality, of constructing a proper identity. While the concept reveals, with its bias toward modernity and rationality, a focus on humanities, it can be applied to the sciences and in particular to mathematics education as a resignification of modernity in education.

It should be mentioned that critiques of Western notions and practice of rationality and modernity are not new. They arose already in the debate about "Orientalism", as instigated by Edward Said in his book, first published in 1978, describing the Orient as a construction of the Occident, of the West (Said, 2003). Likewise, Martin Bernal has shown in his provocative trilogy Black Athena (1987-2003) that the Occident is also a construction, claiming that the origins of modern science are not due to ancient Greece but rooted in Africa.

\section{The rise of public education in pre-modern times}

Pre-modern times in Western Europe meant a decisive break with prior forms of education. Secondary schooling emerged and was linked to some forms of government-i.e., it was no longer run by private or corporate structures. This rise was due to two seminal movements, namely, the establishment of schools with a graded structure of-basically-yearly forms, and the Protestant Reformation and the ensuing Catholic Counter-Reformation.

The establishment of yearly grade schools was due, on the one hand, to reforms within the arts faculty of the universities caused by unrest among the enrolled youngsters: 
increasingly, colleges were created within this faculty, enabling disciplined studies and systematic learning. On the other hand, yearly graded schools had also emerged in some municipal settings, mainly in The Netherlands and Northern Germany, by the end of the middle ages. The best-known school of this type is the Gymnasium in the Protestant city Strasbourg (Schubring, 2014, p. 130ff.).

For both Lutherans and Calvinists, education became the primary field to develop and promote, due to the basic imperative that each believer should be able to achieve his faith by the proper reading of the bible. Thus, each town converted to Protestantism would open schools. Regulations and curricula for the Gymnasien were issued in general by each municipality and thus heterogenous; however, they were dominated by a classical programme, mathematics at first being rather marginal. While most of the Gymnasien were run by the municipalities, in a few Protestant states there were also some Gymnasien instituted by the government, such as the Fürstenschulen in Saxony (Schubring, 2014, p. 132ff.).

The Jesuit order, founded in 1534, ensured quite a success for the Counter-Reformation via its colleges based on a strictly uniform curriculum for all the schools, the Ratio Studiorum. Classical languages dominated and mathematics was restricted to a few months in one of the years of philosophy as, following Aristotle, mathematics had the status of a minor science. Within a few decades, the Jesuits were called to open colleges in almost all the Catholic states, from Spain and Portugal to Italy and France, from Bavaria and Austria to Poland. Catholic secondary education was for a long time practically synonymous with Jesuit education, although other orders opened colleges, later on, too. Who called the Jesuits? It was either magistrates or sovereigns. To run a Jesuit college was an enormously costly enterprise for them as sponsors (ibid., p. 134). Differing from Protestant schools, the Jesuit colleges were not directly of public education status, but in a mediated manner, 'on behalf' of local or national government.

Actually, there was even a third variant, namely, the English education system, based on Anglicanism, beginning with the statutes of Queen Elizabeth I in 1570 and organised in colleges that were undifferentiated into secondary and higher education. Here, logic and rhetoric were dominant, while mathematics again did not have a strong position.

\section{Transmissions by colonial powers to other continents}

The European powers, expanding from about 1500 to other continents, brought their respective systems to their colonies. Yet, one must be aware that the expansion occurred at first-in pre-modern times-in two different manners. There were, on the one hand, those powers that established their own colonies for exploiting resources, basically gold and silver. These were mainly the two countries that initiated the expansion: Spain and Portugal, occupying Central and South America. France followed, with colonies in North America and Africa. On the other hand, there were countries which at first established trading bases along the coasts for commercial interests, for direct access to the precious spices. In such countries, trading companies were created, such as the East India Company (EIC) in Britain and the Westindische Compagnie (WIC) in The Netherlands. Surely, these were not clear-cut or exclusive distinctions. The WIC also tried for a time to establish itself in Brazil and effectively governed a region in the Northwest; they even settled in North America, founding Nieuw Amsterdam, which later became the British New York. Further, while discovering the regions in Asia where the spices were cultivated, they established a colony in what later became Indonesia. ${ }^{1}$

As the powers establishing colonies with their own governments were all Catholic at the outset, it was essentially Jesuit colleges that were implanted in their colonies for the settlers, administration, and some elite among the indigenous: Spanish Latin America, Portuguese Brazil, and French North America all taught the same curriculum. Spanish colonies were the only ones where universities were founded in pre-modern times, already from the sixteenth century: the first one in 1538, in Santo Domingo (Haiti), was established by the Dominican order, and those following were state-run universities. There is little research about their functioning; apparently, they followed the structure of the major Spanish university, at Salamanca. As this university had not been affected by the Humanism reforms, the Spanish universities applied the traditional medieval structure, again with mathematics as marginal (d'Ambrosio, 2014, p. 190). Changes in this situation, which had been stable over centuries, came about during the eighteenth century in the European metropoles, due to the Enlightenment movements and the growing need for technical expertise and training. Decisive signs of this were the expulsion of the Jesuit order from Portugal and its overseas territories in 1759 and the subsequent founding of public education structures. Spain followed suit in 1767.

\footnotetext{
${ }^{1}$ Unfortunately, I did not succeed in finding information about education organised in Dutch India (Nederlands Indie); it was ruled by the trading company VOC (Vereenigde Oostindische Compagnie) and this basically restricted itself to trading stages on the islands. It seems that it turned into a colony (occupying the entire territory) only after the takeover by the Dutch state early in the nineteenth century).
} 


\section{Public school systems in Europe in the wake of the French Revolution}

It was the French Revolution, based on the Enlightenment, that initiated a decisive innovation in European education structures. It was the state that now definitively took over responsibility for organised public education. A characteristic expression of this change was the creation of a dedicated ministry of public instruction in these countries. Due to Cartesian rationality underlying the scientific conceptions of the French Revolution, mathematics became a major school discipline for the first time, opening the way for the realisation of 'mathematics for all'. Condorcet's embracing plan of 1792 was the blueprint for a well-organised public education system.

Yet, this depended on socio-political cycles. In the first secondary schools created after the Revolution, the écoles centrales in 1795, with their offer of courses to be chosen, mathematics was a favourite subject. In the school system established by Napoleon in 1802, the curriculum of the lycées was based on two disciplines, namely, Latin and Mathematics. However, the analytic method no longer dominated: the humanities were praised as providing an eternal model of values, while the sciences were presented as having to abandon their principles each day due to new observations made by chance (see Schubring, 1984, p. 371). A change of the lycées structure in 1809 re-established the dominance of the humanities (Schubring, 1984, p. 372). The restoration period from 1815 reduced the teaching of mathematics in the now colleges royaux to almost the same status as in the former Jesuit colleges, complemented by some special courses for those who wanted to prepare themselves for entering one of the Grandes Écoles (Schubring, 2003, p. 50). To provide the missing teaching of mathematics and the sciences, a second, parallel system of secondary schools was created in 1852 as a bifurcation; however, it suffered a lower social status. Eventually, in 1902, a major restructuration of French secondary school types merged the two schools into one with differentiated branches according to specialisations (Schubring, 2003, p. 52).

A revealing example of the impact of socio-political cycles is provided by Bavaria. In 1808, it created a modern school system with two parallel types of secondary schools: a classical one and a 'realist' one-and with mathematics as a major discipline in both types. Bavaria had been an ally of Napoleon and suffered a heavy restoration period after his defeat. In 1816, the Realschule school type was dissolved and mathematics reduced to a minimal role in the classical type, with just one hour per week. Mathematics teachers were dismissed, and the remaining weekly hour was entrusted to the by-now single generalist teacher in the particular grade. When schools for commercial instruction with more practically oriented mathematics were established in the 1830s, they depended on the Ministry of Commerce. Bavaria continued with such a one-sided classical structure until 1864, even without teaching the sciences (Schubring, 2012, p. 528).

On the other hand, Prussia—not an ally, but defeated by Napoleon in 1806-instigated by this defeat, developed a profound socio-political reform agenda, including decisive educational reforms based on Neo-Humanism. Mathematics became a major teaching discipline in the restructured Gymnasien, analogous to the original Condorcet conception, and was maintained, even against growing conservative pressures (Schubring, 2012, p. 526ff.).

After 1815, Germany consisted of 39 independent political units (kingdoms, grand-duchies, duchies, cities, etc.), so that educational systems with quite different structures co-existed. It was the foundation of the German Reich in 1871 that exerted pressure to homogenise these differences: although only a confederation, there was a need for common requirements. It is telling that the first of such needs was to define the same requirements across the entire Reich, offering reduced military service to Gymnasium graduates. Therefore, the curricula for secondary schools had to be coordinated and aligned to assure the general validity of the Abitur diplomas, of the final examination. The decisions taken in 1874 to define the equivalence of the Abitur diplomas of the federal states approved the lowest Prussian criteria as the common measure (Schubring, 2012, p. 528ff.). By 1900, three types of secondary schools were conferred the right to prepare for higher education according to social class differences, but all with mathematics as a subject for the Abitur exam.

It is well-known that the English state (different from Scotland) did not care much for education for extended periods. For the period up to 1800 , Howson stated that, despite "a marked growth in the applications of mathematics and a need for knowledge of the subject", this did not "cause any government to demonstrate a marked interest in public education" (Howson, 2014, p. 258). This abstinence did not change in the wake of the French Revolution, but only from the 1860 s, for primary and for secondary education. In the first half of the nineteenth century, the leading secondary schools were the famous nine so-called 'public schools', such as Eton and Harrow, which despite their names were private elite boarding schools; they were all dedicated to classical learning with at best some minimal teaching of mathematics. Regarding secondary schools, government actions from 1864 were restricted to recommending modernising the curricula of the various school types which remained in their status as ascribed to three social classes. Mathematics benefitted considerably from these interventions. Yet, it was a type of mathematics well aligned with 
the classical pattern of the schools, featuring Euclidean style geometry.

In the 1870s, initiatives by mathematics teachers rose to challenge the veneration for Euclid and develop more adapted teaching material. Broader success in modernising resulted by 1900 . This was paralleled by steps for public education. The 1902 Education Act established Local Education Authorities (LEAs) and provided for new, publicly funded secondary and technical schools. The decisive step was, however, the Education Act of 1944, which provided state secondary education to all children (Howson, 2014, p. 260ff.).

After the unification of Italy in 1861, ginnasi and licei became the dominant form of secondary schools (its lower and upper departments), applying a strictly humanist curriculum. Mathematics suffered as a secondary subject, its teaching being strongly aligned with the classical style of the school and based on Euclid as a schoolbook. Technicalprofessional training was provided in schools of lesser social status. The attempt to establish a better ranging liceo moderno in 1911, parallel to the liceo classico, was not well implemented. This school type was eventually dissolved in 1923 when the neo-idealist philosopher Giovanni Gentile restructured the entire school system focussed on the humanities, something that had been overcome in all other European countries. Mathematics remained-in a likewise singular manner-a secondary subject (Giacardi \& Scoth, 2014, p. 208ff.).

In Spain, after the Napoleonic wars in 1814, the country suffered political instability and civil wars, affecting education heavily. The first steps towards a public education system were taken in 1821, but a public education system became firmly established only in 1836 . Conservative education ministers were replaced by liberal ones, the first imposing a humanist secondary education and the liberals a modern, science-oriented one. In less than three quarters of a century, more than 25 mathematical curricula were decreed, the most remarkable being those of the years 1836,1845 and 1857. It was the reforms of secondary education from the 1950s on that brought Spanish education into greater alignment with international mathematics reform movements (Ausejo, 2014, p. 286ff.).

Portugal suffered political instability, too, during the nineteenth century. A public education system became firmly established in 1836. The liceus thus established a curriculum with a strong emphasis on mathematics and the sciences. After some alterations, the reform established in 1905-issuing a mathematics curriculum that harmonised with the first international reform movement and introducing the teaching of the calculus-remained in vigour until the 1960s (Matos, 2014, p. 292ff.).

While the mathematics curriculum of the various European countries for their secondary schools evolved during the nineteenth century-independently and according to differing conceptions of the role of mathematics within their respective cultures-one can note the dominance of traditional geometry as a common characteristic; school mathematics remained without connection to the development of mathematics. The twentieth century brought about a modernisation; a first approach was the introduction of the function concept into the curriculum in France in 1902, albeit in a rather isolated manner, not in the mathematics curriculum for the sciences sections of the upper grades, but in the physics curriculum, and there only in the remarks for the teacher (Schubring, 2003, p. 52ff.). A second reform in 1905 extended this more systematically. In Germany, Felix Klein initiated a reform movement to reconstruct the entire curriculum from 1902 based on "functional thinking"; a first decisive result was achieved with the "Meran Lehrplan" of 1905, enacting this functional thinking and leading to the introduction of the elements of the calculus in the upper grades. The founding of the IMUK in 1908 with Felix Klein as president became the means for Klein to launch an international reform movement to disseminate these modernising conceptions. Until the outbreak of WWI, the movement was very active and at least parts of the reform programme were implemented, in particular in Germany, Austria and Hungary, and partially in France. Italy, however, did not implement this reform; the mathematicians there remained too strongly attached to the classicist vision of rigour. In England due to the Perry movement, reforms in teaching methods were realised, but the curricula remained strongly affected by the traditional curriculum.

\section{Education and training during imperialist colonialism}

How did these differing roles of mathematics in the metropoles of the imperialist powers affect their initiatives for teaching in their colonies? Actually, this aspect has so far not been investigated systematically; hence, some scattered results are presented below.

\subsection{Colonial school systems}

First of all, one has to be aware that even during the nineteenth century most European states were restricted to the coastal regions in governing their colonies-and in particular the colonies in Sub-Saharan Africa. ${ }^{2}$ Effective occupation and exploitation began in general only from the last third of the nineteenth century and in particular after the European

\footnotetext{
2 The former colonies of Spain and Portugal had become independent, meanwhile.
} 
powers dared to divide among them what they considered unappropriated world regions.

For this period of what one might call restricted colonialism, the imperialist powers did not engage educational initiatives; colonial administrators would be trained in the homeland and transferred to their site of operation. If ever there were initiatives for education, these were schools run by missionaries addressing at least parts of the local population. Examples of this are Mozambique and Angola, where there were two categories of schools before independence, as follows.

Government schooling was reserved almost exclusively for the children of the settlers, particularly at the levels of secondary and higher education. The few Mozambicans who had access to schools were taught at the Roman Catholic mission schools. (Gerdes, 1981, p. 457)

In fact, the native fighters for independence used to be students of the missionary schools. Upon gaining independence in 1975, the illiteracy rate in Mozambique was still about 93\%. In Dutch Indonesia, where colonial power was for a long time restricted to the coastal regions, schools for larger regions were opened after WWI due to the first political movements in the colony.

The other pattern was regions where some schooling had existed before colonisation; there, a parallel system instituted by the colonial power emerged alongside traditional schooling. This pattern is here considered for some of the Arab states.

A first telling case is Egypt, even before British rule. From 1805, Muhammed Ali Pasha, its suzerain governor dependent on the Ottoman Empire, effected a strict modernisation of the country. There was a traditional system of learning, formed by kuttab for basic learning and madrasa for higher learning, directed by the Ulema. Ali Pasha was not sufficiently strong to modernise this system, too; thus, he began to establish public schools as a parallel system. In 1815 , he created the first non-traditional school in the Citadel of Cairo; it became later known as the Mühandishane and functioned as a polytechnic school. Beginning in 1821, preparatory schools were created. This parallel system did not survive Ali Pasha's regency, however (Abdeljaouad, 2012, p. 490).

In Tunisia from the 1820s, the ruling Beys, likewise Ottoman suzerains, tried to modernise the traditional system. A modern public school, the Sadiqi college, was established, and the traditional leading institution, the madrasa within the Zaytüna mosque, was somewhat modernised. When France occupied Tunisia in 1881 as a protectorate, a liberal French policy at first backed this system. After 1907, however, France began systematic colonisation. They created two new, parallel systems of education: a French one and a
Franco-Arabic one. The French schools were designed for French and other European children, mostly non-Muslim; they applied the same curriculum as in France, including for mathematics. Thus, the secondary schools applied the same structural changes for mathematics as in France. The Franco-Arabic primary schools, created in almost all cities and under French colonial direction, offered basically the same curriculum as the French ones-but with the Arabic language for European children and religious lessons and classical Arabic language and grammar for Muslim children. Since modernised kuttabs were founded by private individuals and associations (known as the modern Qur'an schools), there were altogether four parallel types of schools. While the formerly leading Sadiqi college was downgraded "to train mid-level civil servants, well-grounded in the Muslim culture [...] capable of becoming good interpreters and intermediaries between the French authorities and the Tunisian administration", the leading secondary school in Tunisia became the Lycée Carnot (Abdeljaouad, 2014, pp. 414ff. and 420). ${ }^{3}$

The case of Spanish Morocco confirms the parallelism between continued traditional school systems and colonial ones and confirms, too, the politically intended differentiation of the colonial system. France and Spain had decided in 1912 to divide Morocco among themselves and govern it as their colonies, naming them protectorates.

Spain invested enormous energy in establishing a colonial school system. The existing system of three traditional school types became complemented by three new types of schools, as follows:

- Spanish schools for the settlers and some Moroccans near the colonial government (administration, etc.). The teachers came from Spain and instruction was given in Spanish;

- Hispano-Arab schools for Moroccans, with teaching given in Spanish and teachers also from Spain;

- Hispano-Hebrew schools for the Jews in some of the urban centres.

Besides this colonial system, in the 1920s, the so-called nationalist schools appeared, founded by the nationalist movement with instruction in Arabic.

Eventually, there were the traditional schools, besides the evident Qur'an primary schools and Talmud schools; none of these were controlled by government but by the respective communities, the Ulemas and the rabbi. (Schubring, 2017, p. 357).

\footnotetext{
3 Abdeljaouad analysed the mathematics teaching content in the various school types (Abdeljaouad, 2014).
} 
In the French protectorate of Morocco, a strict separation was established between the French schools, again for French settlers and functionaries, and Arab schools that should not enable entry to French higher education. The mathematics teaching in the Arab schools improved but had to remain restricted to a level that would not cause resistance from the Ulemas. A 1933 decree for mathematics at the Arabic secondary schools alerted officials and teachers that the contents should not be "opposed to the $\operatorname{shart}^{c} a$ or disturb learning the basic religious sciences" (quoted from: Abdeljaouad, 2014, p. 412).

\subsection{Two forms of orientalism}

British India presents the most marked case of a clash between established indigenous cultures and colonialist intervention. In fact, India is a key example of a country with a millennial culture, in particular for science and mathematics. During the nineteenth century, it became the colony of the strongest imperialist power, with the British King as the Emperor of India. This change originated from the EIC's venture for trade. Founded in 1600 to trade in the Indian Ocean region, it had not intended to rule India, nor likewise to organise education. Eventually, however, British-India became the first colony to found universities, during the imperialist period. By the middle of the eighteenth century, the EIC had expanded enormously in India, politically and economically, and even in the inland regions of Calcutta, Bombay and Madras. Founding schools there had two origins. One origin was the needs of the EIC for trained personnel. At first, the EIC sent employees called 'Factors' to administer business affairs abroad. From 1765, they sent 'Writers', i.e., clerks and copyists, without specific training beyond classical languages and commerce; they were meant to acquire specific knowledge as apprentices of senior officers. By 1796, the company understood that they needed officers trained as civil servants and with knowledge of local languages; thus, it founded its own colleges in England (Aggarwal, 2006, p. 8).

The second origin was initiatives by British settlers from the 1780s to found colleges - at first in Calcutta and in Benares-parallel to the traditional schools that existed for the Hindu and Muslim population, and thus for teaching in Sanskrit and in Arabic. Also in the 1780s, British scholars initiated translations of Indian manuscripts of literature and science into English. Charles Grant (1746-1823), for a long time an EIC Writer in Calcutta, proposed to the EIC in 1792 that education be established in British India. While his proposal was disregarded then, he put it into action after becoming Director of the EIC in 1805 (Aggarwal, 2006, p. 84ff.).

The original conception of this education was the founding of "Oriental colleges" teaching in the local language, i.e., generally Arabic or Sanskrit. While aiming at educating colonial citizens able to administer the colony on adapted lines, the company's officials were careful not to intervene in existing systems of education until the 1830s. This was the same period when the first generations of orientalist scholars began to unearth the knowledge accumulated on this subcontinent within the Sanskrit and Indo-Persianate universes. Significant for this period of true orientalismcontrary to the later notion of "orientalism" as analysed by Edward Said (2003) — Friedrich August Rosen (University of London) and Henry Thomas Colebrooke researched Sanskrit mathematical texts and published the first translations. These orientalists assessed that Sanskrit arithmetic and algebra were grounded on the same principles as those of Europe (Raina, 2014, p. 378).

A decisive break occurred, however, in 1835 , with the assumption that the Indian population was uncultured and in need of enculturation by British standards. This break, imposing crude colonialism, was brought about by the British historian and Whig politician Thomas Babington Macaulay (1800-1859), who served from 1834 to 1838 as president of the General Committee of Public Instruction in British-India. His emblematic "Macaulyan Minute" of 1835 ridiculed traditional Sanskrit knowledge. Macauley called the local languages "poor and rude" and claimed it unexaggerated "to say that all the historical information which has been collected from all the books written in the Sanskrit language is less valuable than what may be found in the most paltry abridgments used at preparatory schools in England". Works on science he referred to as, among other things, "astronomy which would move laughter in girls at an English boarding school" (Macaulay, 1835, pp. 8 and 13). Teaching in native languages had, therefore, to be substituted by teaching in English, attributing this language a value analogous to the venerated Greek language:

We have to educate a people who cannot at present be educated by means of their mother-tongue. We must teach them some foreign language. The claims of our own language it is hardly necessary to recapitulate. It stands pre-eminent even among the languages of the West. It abounds with works of imagination not inferior to the noblest which Greece has bequeathed to us (Macaulay, 1835, p. 12).

The aim of the anglicised oriental colleges was to "form a class who may be interpreters between us and the millions whom we govern". This class might have the additional task "to refine the vernacular dialects of the country, to enrich those dialects with terms of science borrowed from the Western nomenclature" (Macaulay, 1835, p. 34).

In the first decades of the nineteenth century, the EIC sent teachers from England, trained there at a special college established by the company in Haileybury. Textbooks used there for teaching were different from those of the 
Euclid-style used at Cambridge and Oxford. And the library there holds, among others, Colebrooke's translation of Brahmagupta and Bhaskara and Edward Strachey's translation of the Bija Ganita (Aggarwal, 2006, pp. 18 and 27). At the EIC's Military Seminary in Addiscombe for cadets for military service in the colony, the much more modern textbook in use was by Charles Hutton, A Course in Mathematics, also in use at the Military Academy Woolwich (ibid., p. 42). Yet, when the British Crown dissolved the EIC and took over direct control of British-India in 1858, teachers now came mainly from the English universities, with the effect that Euclid came to mould the teaching of geometry (ibid., pp. 201, 207, 236).

\section{Post-colonialism: coloniality and decoloniality}

Despite the differences between countries, in particular the major European ones, there is a common impression or even conviction of homogeneity of mathematics teaching worldwide. The Finnish mathematics educator George Malaty (1999) wrote as follows:

Till the end of the school year 1957/1958 school mathematics was quite the same everywhere. Primary school mathematics mostly consisted of arithmetic. Secondary school mathematics was mostly algebra and plane Euclidean geometry, and in the upper grades algebra, analytic geometry, solid Euclidean geometry and trigonometry. In the 1950 s calculus teaching spread in upper secondary school. (p. 231)

According to Malaty, diversity began as a consequence of the Sputnik shock and the ensuing modern mathematics movement launched by the Royaumont Seminar in 1959. There is likewise a widespread opinion that modern mathematics affected all countries in the same way. However, identical labels such as 'arithmetic' or 'algebra' do not mean the same teaching: beyond identical titles, very different conceptions of teaching are revealed when looking behind the surface regarding embraced content of topics, their teachability and their epistemological valorisation.

It is rarely noted that the period of worldwide dissemination of modern mathematics practically coincided with the period of decolonisation. Remarkably, in all the public education systems now established in decolonised countries, mathematics was accepted as one of the principal teaching disciplines. When reflection about the form of mathematics teaching for the then so-called Third-World began, it was formulated again as an affirmation of a common practice of mathematics teaching in the 'West', i.e., in Europe and the United States. It was Bienvenido Nebres, a Jesuit from the Philippines, highly active in ICMI in the 1980s for third-world issues, who strongly influenced international discourse in mathematics education about these issues. Nebres based his discussion on historical affirmations made by Peter Damerow, a West-German mathematician dedicated to the history and teaching of mathematics, in resuming what Damerow maintained as two concerns:

The first is that the canonical school curriculum for mathematics [in Europe] was designed for an elite and so there are serious adjustment problems when it is made universal. (Nebres, 1988, p. 18)

The term "canonical" shows the assumption of a universal curriculum in Western countries; moreover, the affirmation that it served for an elite is historically wrong: surely, secondary schools were not attended by all, but the curriculum was designed for general education and not only for certain professions or to prepare for university. The second concern underlined the supposed unity of Europe:

The second is that it was designed for a European elite and so the adjustment problems become even more serious when it is introduced into the mass educational system of a developing country (Nebres, 1988, p. 18)

Nebres even quoted directly from a paper by Damerow on "a specific Western European cultural tradition":

The transfer of this curriculum to developing countries in most cases has been closely linked with the institutionalization of schools by colonial administrations in these countries. It is well known that these schools generally were attended only by an elite, which adopted the Western European culture and often studied afterwards at European universities. Under these conditions it seemed natural simply to copy the curriculum of higher education, (p. 18)

In fact, as already discussed, the schools founded by the imperialist powers in their colonies served to educate their settlers and a selection of the natives who would serve in the colonial administration. Copying from the metropolitan curriculum was not, however, the general pattern, and definitely not from a university curriculum. And continuing to a university in Europe after attending a colonial school happened surely not as "often". Yet, Nebres depicted well the challenge after decolonisation to transform the inherited colonial school system into a new public school system that fitted in with the country's specific cultural contexts:

All of the countries of Southeast Asia, with the exception of Thailand, went through a prolonged colonial period. During the colonial period, the school system was patterned exactly after that of the colonising country. The norms of fit between school and society were quite precise: the school system was to come 
Fig. 1 Similarity, according to School Mathematics of East Africa, Book 2, p. 210

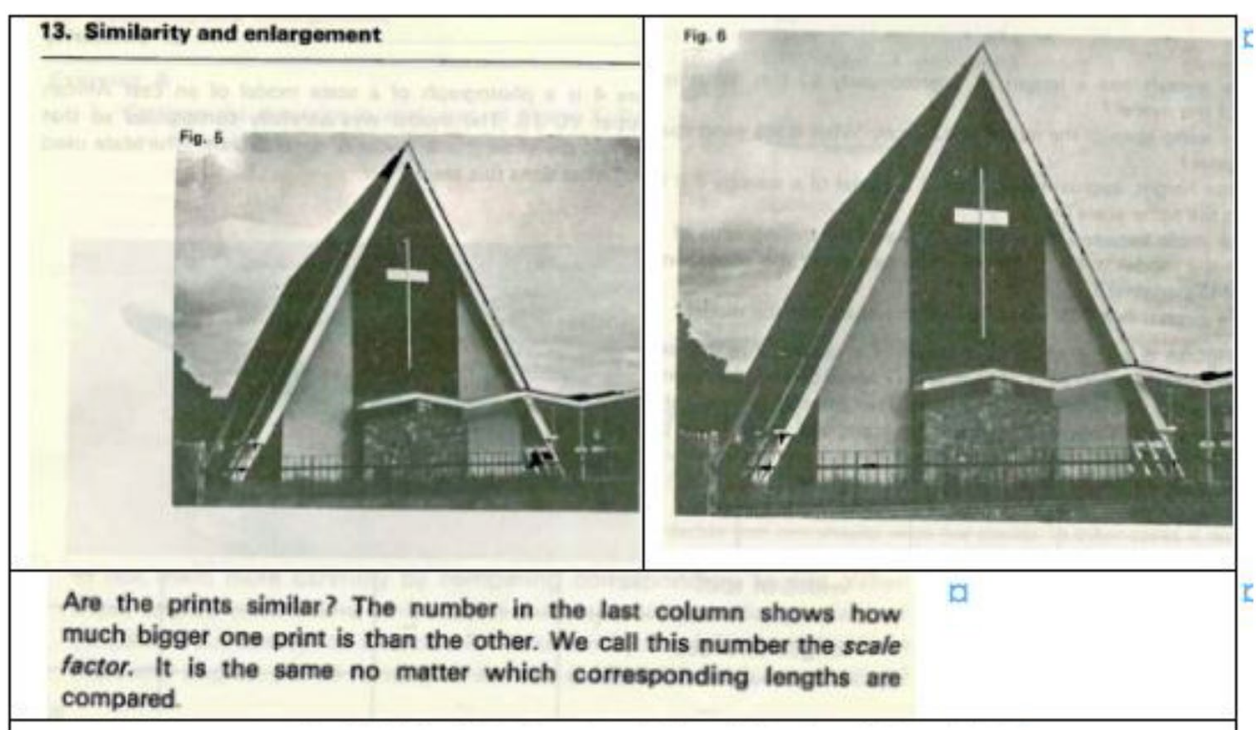

as close as possible to that of the mother country. It should produce graduates that would fit into the civil service and who would do well in universities in the mother country. With independence the above norms of fit between school and society were seen with mixed feelings. Leaders became conscious that a school system developed according to such norms would, among other things, simply contribute to the brain drain. They also became conscious that the school system had to respond to different cultures and classes in the country: a westernized elite, a growing lower middle class, urban workers, a traditional rural sector. (p. 18)

The desired decoloniality proved, however, difficult to achieve due, on the one hand, to internal factors (the political elite having been acculturated by the former colonisers) and, on the other hand, to external, coloniality pressures (economic pressures, for instance to use the metropolitan textbooks). This problematic question is first illustrated below by the case of former British East Africa, covering Uganda, Kenya and Tanganyika. The textbooks elaborated during decolonisation were tutored from the metropoles:

Modern mathematics reforms that took place in the1960s and 1970s in Britain and in the United States of America informed the previous Uganda mathematics teaching syllabi at primary, secondary and teacher training levels. Several of the curriculum and textbook writing projects involved multilateral efforts and served numerous African countries. The first editions of the School Mathematics for East Africa, SMEA and of the Entebbe Math textbooks it is claimed, for example, were written to adapt the British School Mathematics Project (SMP) and the American School Mathematics Study Group (SMSG) approaches to the education systems of East African and of selected subSaharan African countries, respectively. (Namukasa, Kaahwa, Quinn, \& Ddungu, 2011)

The leading series School Mathematics of East Africa gives no names of its authors and thus does not show who of the original SMP authors contributed and tutored. The preface claims that the SMP was revised to be "more appropriate for the local situation, by men and women teaching in East Africa" (School Mathematics of East Africa, Book 1, 1969a, p. iii). Illustrations in this textbook series show that Christian faith is assumed as the decisive cultural orientation of East Africa, although there are strong communities there of African, Islamic and Indian religions (Fig. 1). Surely, missionaries had founded many schools in these countries, but the manner in which the geometrical notion of similarity is introduced reveals coloniality practices.

It is likewise revealing that in former British West Africa, the same mathematical notion was presented in a textbook of 1985 for Nigeria, although it was also produced in England, in a non-colonial manner, featuring proper cultural figures (Fig. 2): ${ }^{4}$

Examples for self-instigated decolonial developments and external coloniality pressures are mentioned below for Niger and for Mozambique.

In the Republic of Niger, a former French colony, independent from 1958, schoolbooks-at least from the 1980swere elaborated according to original African cultural values as related to the conception of Négritude by INDRAP, the Institut National de Documentation, de Recherche et

\footnotetext{
${ }^{4}$ One can assume that the notion of similarity was inherited from classical British geometry curricula, but it is reasonable, too, to think that it would make sense in any curriculum of plane geometry.
} 
Fig. 2 Similarity, in a Nigerian schoolbook (Channon et al. 1987, p. 10)
8 Look at each pair of diagrams in Fig. 2.6. Say whether they are similar or not. Use measurement to help you if you are not sure.

(a)
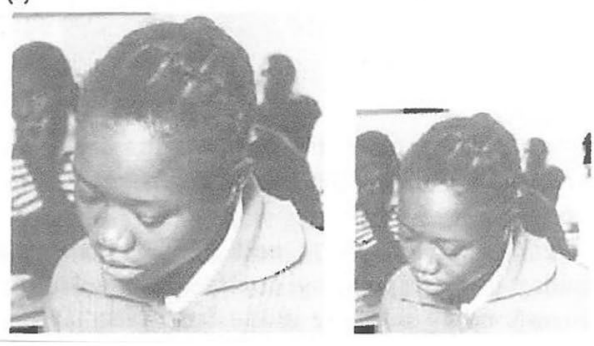

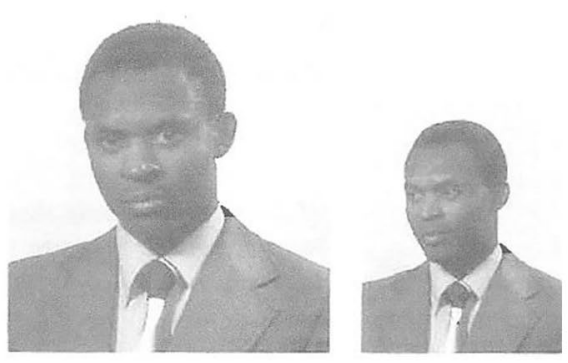

Fig. 2.6

\section{1 \\ .}

Specifically telling were the three Maghreb countries Tuni-

d'Animation Pédagogique at Niamey. The mathematics books were elaborated by teams of teachers from Niger and with the conceptual contribution of Ghislain Spaak, a member of the NGO Eirene. Spaak (died in 2011) originated from Belgium but lived in Niger from the early 1980s. I know from many conversations and cooperation with him how difficult it was for INDRAP to resist ever-increasing pressure from France to adopt their mathematics schoolbooks again; later on, this pressure was taken over by the World Bank, which wanted (in the context of aid for development) the Ministry to suppress innovative developments and return to importing French textbook series (Fig. 3) featuring white, European students and teachers, and word problems stressing inner-European issues). However, in Niger Republic, they basically succeeded in continuing to develop their own schoolbook series. The following illustration documents decolonial practice:

In Mozambique after its independence in 1975, great efforts were made to elaborate textbooks rooted in African culture. The two new textbook series-Eu vou à Escola: Matemática [I am going to school: mathematics] for primary grades, and Eu gusto de matemática [I like Mathematics] and Matemática? Claro! [Mathematics? Sure!] for secondary grades-constitute very significant cases for decolonial practices. Here are two examples from the primary grades series (Fig. 4).

After the end of the Apartheid regime in South Africa and its involvement in Mozambique's policy, the country applied for international monetary funds; pressure by the World Bank effected that textbooks from Portugal had to be introduced. Eventually, the IMF established the requirement for financial support for developing countries that any publisher in the world should be admitted to collaborate in the production and publication of textbooks.

Another highly sensitive issue in the decolonisation process was the language to be used in the school system. sia, Algeria and French Morocco where the metropole had imposed French as the language for teaching. Changing the language to Arabic resulted in different practices of decoloniality in the three countries, and this in particular regarding a specific heritage of Arabic development of mathematics: the writing direction of mathematical notations called "bilaterality", where the Hindu-Arabic numbers and formulas used to be written from the left to the right and the surrounding text from right to left. There were decolonial practices, which made it difficult for graduates to communicate internationally (see Schubring, 2017, p. 354ff.).

Yet, the language issue is even more sensitive for the decolonisation issue in regions, like sub-Saharan Africa, where the colonial powers defined frontiers between their colonies without any respect to the language of the peoples living there, resulting in the language of the colonisers becoming the 'lingua franca' in the independent states, despite or due to the variety of local and regional languages there-an ensuing burden of colonialism.

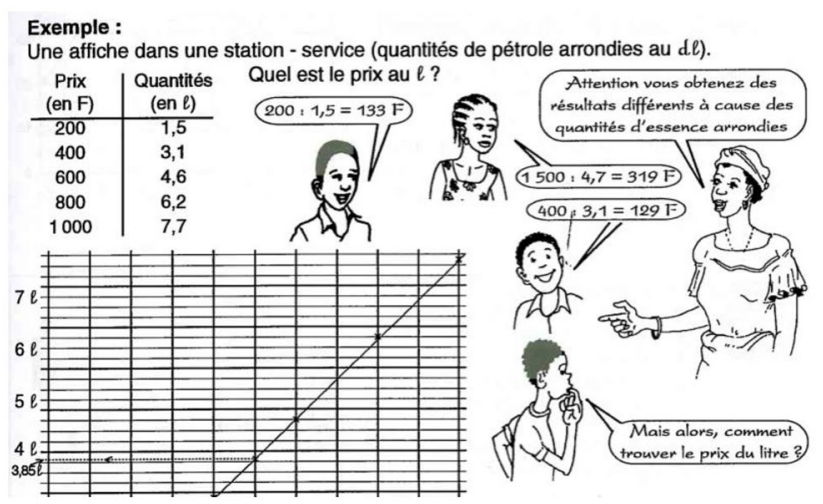

Fig. 3 Ibo et al. 1995, p. 31 
Fig. 4 Cover of Draisma et al. 1984a, and p. 11 from Draisma et al.1984b

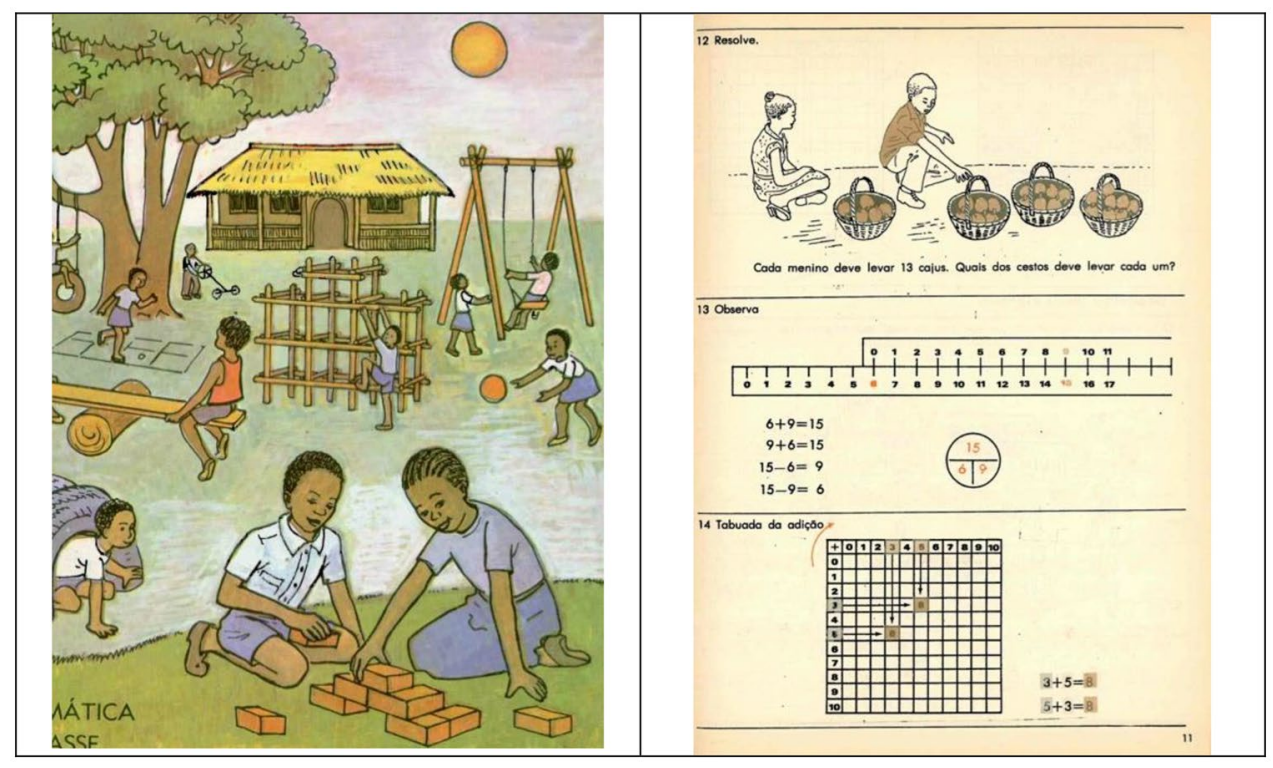

Admittedly, Walsh's (2018, p. ii) programmatic claim that decoloniality should "displace Western rationality as the only framework and possibility of existence, analysis, and thought" is quite strong, and one would have to analyse more deeply how far it applies to mathematics textbooks in former colonial countries. Admittedly, too, mathematics is not as intimately tied to a 'mother' country's values and norms as some other disciplines, the paradigmatic example being history, which used to be taught in every French colony as history of France, according to the proper French textbooks. The major emphasis was, surely, on humanities school disciplines. On the other hand, as the former discussion showed, mathematics teaching did serve to disseminate ideologies of white superiority and perpetuate race and gender stereotypes. It was in no way exempt from coloniality.

\section{New colonialities}

The concepts of coloniality and decoloniality can also be applied, according to Walsh and Mignolo, to post-Sovietstudies. This paper does not attempt to complete this work in full: only two observations are presented below for mathematics education.

\subsection{Post-Soviet studies}

To succeed in finding differences between socialist and postSoviet periods, one should identify ideologically loaded issues of either mathematics education or of school education in general that can show telling differences. One such issue surely constituting a key factor for political decisions about education is presented by the school structure itself. From the establishment of public education systems during the nineteenth century, there were socially segregating school types on the primary and secondary school levels. In Germany, for instance, there were three different types of secondary schools from 1900, each one giving access to higher education. Officially, the social classes were disguised by claiming the existence of differing ability structures of the students that were addressed by these types. Mathematics was heavily involved in these social segregations: curricula and teaching methods were designed according to the alleged differences in giftedness. Socialist education denounced these segregations by social classes; the socialist countries emerging in Eastern Europe after WWII thus replaced segregating structures with-in principle-a single, comprehensive school type.

During the 1960s, the traditional class structures, vested by an ability discourse, were also questioned in Western countries. While the United States always had a single system, comprehensive schools were founded in England. And in the Federal Republic of Germany (FRG), analogous Gesamtschulen were created. In both countries, social movements were not strong enough to replace the old system so that it became an additional structural element. In the FRG, there were then four parallel types of secondary schools leading to the Abitur. While there was a reform for the last three grades in 1972-uniting the different schools into one Oberstufe, with streaming according to interest profiles and the maintenance of a basic course in mathematics as compulsory for all streams - the four parallel types were maintained for the lower grades.

When the GDR attached itself to the FRG in 1990, the new federal states there had to abandon the comprehensive schools and introduce at least one additional type: clearly, a different mathematics curriculum had to be designed for it. Bruder (2020, p. 52) mentions this rupture only randomly as 
a "debate" that continued "to smolder in the background". Meantime, this probably was the most palpable post-Soviet effect in the ex-GDR. It was, however, an interesting example of return to the policy which was considered by many to be archaic even in the old states of FRG.

Another revealing issue is presented by the discussion of public education organised by the state, since the French Revolution. Tellingly, it had been the Catholic Church that had led a forceful and persisting campaign in France, during great parts of the nineteenth century, against an alleged "monopoly" of the state for organising schools, using "liberty" as a catch-word for the fight against a lay school system and aiming to have schools under clerical control as in Jesuit times. For post-Soviet Hungary, one can observe a similar rhetoric: the 1990 law enabled "churches and other legal entities to set up and maintain schools" (Győri, 2020, p. 87).

\subsection{PISA as global curriculum agency}

One new dimension of global coloniality can be revealed by the analysis of the attempts of post-Soviet Eastern European countries to follow the requirements and results of international achievement tests. An international agency, PISA (Programme for International Student Achievement), is accepted as a criterion for determining the local mathematics curriculum. What is at stake?

PISA was launched by the OECD, the Organisation for Economic Cooperation and Development. It was created in 1947 as an agency of the Cold War to administer the US-funded Marshall Plan, ${ }^{5}$ the enormous fund for rebuilding Western Europe's infrastructure after World War II and improving the economy of these countries in order to face the challenge from socialist countries. The impact of the OECD organised colloquium in France at Royaumont in 1959 for launching international reform of modern mathematics is well-known.

Since 1997, the OECD has assumed, however, a new global role inspired by a conception realised earlier by TIMSS. The difference between TIMSS and PISA needs to be explained, since both seem to undertake analogous studies. The first agency organising international comparative achievement evaluations had been the IEA (International Association for the Evaluation of Educational Achievement), an international cooperative of national research institutions, governmental research agencies and scientists. Addressing mainly the mathematics education communities, their evaluations since the 1970s did not garner much attention. However, in 1995 their TIMSS - Third International Mathematics and Science Study_had important impacts: not only in the world of education, but also in politics, due in particular to

\footnotetext{
5 At first named Committee for European Economic Co-operation.
}

the new feature of video-studies recording and comparing mathematics teaching practices in the classrooms in three countries, in a much more palpable manner.

While the IEA continues to undertake comparative studies in TIMSS style, the leadership in public attention, in particular by politicians, is occupied by PISA, launched in 1997 by the OECD, usurping the IEA procedure, to inform education policy makers about failures and weaknesses in the assessed countries according to their criteria, measuring another kind of achievement. According to the PISA site, the difference from TIMSS is that both ...

test different things. TIMSS is curriculum-based whereas PISA assesses the application of skills to real-life problems. TIMSS focuses on content normally covered in class while PISA evaluates overarching content categories that go beyond curricula. PISA also emphasises the importance of the context in which students should be able to use their skills (schools, home and society).

A large number of states undertake, with increasing pressure from the OECD, the PISA tests designed by the OECD to reform the teaching of mathematics and science in order to achieve better results in the next test. The OECD publishes a ranking list of the position of each country participating, and the position of the country itself in that ranking is already the main element of discourses on the quality of education in the particular country, particularly in mathematics. The results are appreciated as objective and the politicians and educators of each country feel obliged to act to improve the results; they understand the results as an imperative to guide their own educational policy. Since the OECD is an organisation to, at least, inform-if not guideeconomic policies, under the hegemony of Western states, in particular the United States, it can be concluded that OECD pressures to follow and apply their warnings and guidelines on national education policies are not the result of simple benevolence for education, nor in particular for the teaching of mathematics, but of a new style of coloniality.

What is the conceptual basis for PISA assessments? The origin is the Dutch conception of Realistic Mathematics Education, with its focus on the applicability of learned knowledge to real life. This concept was adapted by the OECD through the concept of competencies, which should indicate these skills of application. The following quotation from the study of post-Soviet Polish mathematics education illustrates the attitude to PISA achievements and its results:

In the PISA 2000 study, Polish students obtained 470 points, which placed them on the 25th position among 41 countries which took part in the survey. Twelve years later, in 2012, the average mathematical result of Polish students was 518 points. This put them at 13 th 
place among 65 countries and economies participating in the survey and fourth among European Union countries. Polish students have achieved a level of mathematical skills identical to Canadian students and statistically indistinguishable from Finnish students (Karpinski, Swoboda, \& Zambrowska, 2020, p. 158).

Clearly, with PISA exerting hegemonic control of curricula and with the conception of skill-focused competencies, curricula are dominated by criteria of the labour markets and economic values, marginalising objectives specific to education, citizenship and cognitive development.

\section{Conclusion}

While mathematics began to emerge as a school discipline together with public education in Europe, European states, as they simultaneously transformed into colonial powers, transferred some colonially-differentiated early forms of mathematics teaching. Extending colonialism to imperialism during the nineteenth century, mathematics became a part of a more developed system of education for colonial aims. After gaining independence, the developing countries of the Third World integrated mathematics into their public school systems. Given that Nebres' simplifying assertion according to which there was a "canonical school curriculum for mathematics" in Europe (quoted above) blurs the marked differences between the former colonial powers, one needs more detailed studies on how textbook production and teacher training in the former colonies dealt with the colonialities imposed by their respective former colonial power, how they developed decoloniality practices, and the obstacles with which they were confronted.

Yet, despite the end of openly colonial regimes, not only do traditional forms of coloniality continue to be influential, but new, sophisticated materialisations of coloniality emerge and impact mathematics teaching globally.

Acknowledgements I am thanking Márcia Maria Fusaro Pinto, who first brought me in contact with the concepts of coloniality and decoloniality-concepts suggesting themselves much more as obviously pertinent when living within the Southern hemisphere than within Old Europe.

Funding Open Access funding enabled and organized by Projekt DEAL.

Open Access This article is licensed under a Creative Commons Attribution 4.0 International License, which permits use, sharing, adaptation, distribution and reproduction in any medium or format, as long as you give appropriate credit to the original author(s) and the source, provide a link to the Creative Commons licence, and indicate if changes were made. The images or other third party material in this article are included in the article's Creative Commons licence, unless indicated otherwise in a credit line to the material. If material is not included in the article's Creative Commons licence and your intended use is not permitted by statutory regulation or exceeds the permitted use, you will need to obtain permission directly from the copyright holder. To view a copy of this licence, visit http://creativecommons.org/licenses/by/4.0/.

\section{References}

Abdeljaouad, M. (2012). Teaching European mathematics in the Ottoman Empire. ZDM - The International Journal on Mathematics Education, 44(4), 483-498.

Abdeljaouad, M. (2014). Mathematics education in Islamic Countries in the modern time. In A. Karp \& G. Schubring (Eds.), Handbook on the history of mathematics education (pp. 405-428). New York: Springer.

Aggarwal, A. (2006). British higher education in mathematics for and in Asia, 1800-1880. Ph.D. thesis. Middlesex University, Enfield.

d'Ambrosio, U. (2014). Mathematics education in Latin America. In A. Karp \& G. Schubring (Eds.), Handbook on the history of mathematics education (pp. 186-196). New York: Springer.

Ausejo, E. (2014). Spain. In A. Karp \& G. Schubring (Eds.), Handbook on the history of mathematics education (pp. 284-291). New York: Springer.

Bruder, R. (2020). Traditions and changes in the teaching and learning of mathematics in Germany. In A. Karp (Ed.), Eastern European mathematics in the decades of change (pp. 45-74). Cham: Springer.

Channon, J. B., McLeish Smith, A., Head, H. C., Macrae, M. F., \& Kibui, P. W. (1987). General mathematics for secondary schools. Harlow: Longman.

Draisma, J., Marques H. G.l., Silva, J., Soares, M. do C., Cardoso, V., \& Rödel, W. (1984a). Eu gosto de matemática. 2.a classe. Maputo: Instituto Nacional de Desenvolvimento da Educaçao.

Draisma, J., Marques H. G.1., Silva, J., Soares, M. do C., Cardoso, V., \& Rödel, W. (1984b). Eu gosto de matemática. 2.a classe - Caderno de exercício, vol. 1. Maputo: Instituto Nacional de Desenvolvimento da Educação.

Gerdes, P. (1981). Changing mathematics education in Mozambique. Educational Studies in Mathematics, 12, 455-477.

Giacardi, L., \& Scoth, R. (2014). Secondary school mathematics teaching in Italy. In A. Karp \& G. Schubring (Eds.), Handbook on the history of mathematics education (pp. 201-228). New York: Springer.

Györi, J. G. (2020). The traditions and contemporary characteristics of mathematics education in Hungary in the post-socialist era. In A. Karp (Ed.), Eastern European mathematics in the decades of change (pp. 75-129). Cham: Springer.

Howson, G. (2014). England. In A. Karp \& G. Schubring (Eds.), Handbook on the history of mathematics education (pp. 258-269). New York: Springer.

Ibo, I., Rapkatou, D., \& Ghislain S. (1995). Mathématiques. CM 2. Livre de l'élève. Niamey: INDRAP.

Karpinski, M., Swoboda, E., \& Zambrowska, M. (2020). Changes in Polish school mathematics education in the years 1989-2019. In A. Karp (Ed.), Eastern European mathematics in the decades of change. Cham: Springer.

Macaulay, T. B. (1835). Minute by the Hon'ble, T. H. Macaulay, dated the 2nd February 1835. http://www.mssu.edu/projectsouthasia/ history/primarydocs/education/Macaulay001.htm

Malaty, G. (1999). The Third World mathematics education is a hope for the world mathematics education development in the $21 \mathrm{st}$ century. In A. Rogerson (Ed.), Proceedings of the international conference Mathematics Education into the 21st Century (pp. 231-240). Cairo. 
Matos, J. (2014). Portugal. In A. Karp \& G. Schubring (Eds.), Handbook on the history of mathematics education (pp. 291-302). New York: Springer.

Namukasa, I. K., Kaahwa, J., Quinn, M., \& Ddungu, R. (2011). Critical curriculum renewal in Africa: The character of school mathematics in Uganda. In A. Abdi (Ed.), Decolonizing philosophies of education (pp. 177-193). Rotterdam: Sense.

Nebres, B. F. (1988). The problem of universal mathematics education in developing countries. In P. Damerow, M. E. Dunkly, B. F. Nebres, \& B. Werry (Eds.), Mathematics for all (pp. 18-22). Paris: UNESCO.

Raina, D. (2014). Mathematics education in modern India. In A. Karp \& G. Schubring (Eds.), Handbook on the history of mathematics education (pp. 376-385). New York: Springer.

Said, E. W. (2003). Orientalism. London: Penguin Books [first edition 1978].

School mathematics of East Africa. (1969a). Book 1. Cambridge: Cambridge University Press. [no authors given].

School mathematics of East Africa. (1969b). Book 2. Cambridge: Cambridge University Press. [no authors given].

Schubring, G. (1984). Essais sur l'histoire de l'enseignement des mathématiques, particulièrement en France et en Prusse. Recherches en Didactique des Mathématiques, 5, 343-385.
Schubring, G. (2003). L'EnseignementMathématique and the First International Commission (IMUK). In D. Coray, F. Furinghetti, H. Gispert, B. R. Hodgson, \& G. Schubring (Eds.), One hundred years of L'EnseignementMathématique (pp. 47-65). Geneva: L'EnseignementMathématique.

Schubring, G. (2012). Antagonisms between German states regarding the status of mathematics teaching during the 19th century: Processes of reconciling them. ZDM - Mathematics Education, 44(4), 525-535.

Schubring, G. (2014). Mathematics education in catholic and protestant Europe. In A. Karp \& G. Schubring (Eds.), Handbook on the history of mathematics education (pp. 130-143). New York: Springer.

Schubring, G. (2015). From the few to the many: On the emergence of "Mathematics for All." Recherches en Didactique des Mathématiques, 35(2), 222-260.

Schubring, G. (2017). Mathematics teaching in the process of decolonisation. In K. Bjarnadóttir, F. Furinghetti, M. Menghini, J. Prytz, \& G. Schubring (Eds.), "DIG WHERE YOU STAND” 4 (pp. 349 368). Roma: Edizioni Nuova Cultura.

Walsh, C. E. (2018). Decoloniality as/in practice. In W. D. Mignolo \& C. E. Walsh (Eds.), On decoloniality: Concepts, analytics, praxis (pp. 15-102). Durham and London: Duke University Press. 
Publisher's Note Springer Nature remains neutral with regard to jurisdictional claims in published maps and institutional affiliations. 